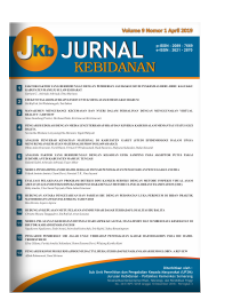

Volume 10 Nomor 1 (2020) 37-42

JURNAL KEBIDANAN

p-ISSN: 2089-7669 ; e-ISSN: 2621-2870

https://doi.org/10.31983/jkb.v10i1.5427

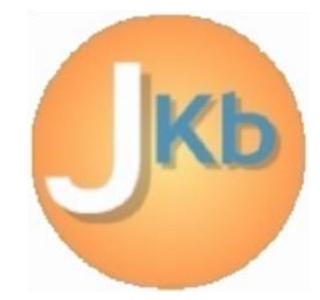

\title{
Effectiveness of Consumption Iron Tablets with Orange Juice to Increase Hemoglobin Levels in Pregnancy
}

\author{
Tupriliany Danefi", Hapi Apriasih \\ Department of MidwiFery, Sekolah Tinggi Ilmu Kesehatan (STIKes) Respati Tasikmalaya \\ Jalan Raya Singaparna KM. 11 Cikunir Tasikmalaya, Indonesia \\ Corresponding author: Tupriliany Danefi \\ Email: tuprilianydanefi07@gmail.com
}

Received: November $22^{\text {th }}, 2019$; Revised: March $19^{\text {th }}, 2020$; Accepted: March $23^{\text {th }}, 2020$

\begin{abstract}
Pregnant women have a risk of anemia. The incidence of anemia in first trimester of pregnancy is $20 \%$, second trimester of $70 \%$ and third of $70 \%$. More than $3 / 4$ pregnant women experience iron deficiency and more than $1 / 3$ pregnant women have anemia.The purpose of this research was to determine effectiveness of consumption iron tablets with orange juice to increase hemoglobin levels in pregnancy in the working area of Singaparna Public Health Center Tasikmalaya in 2019. Research used quantitative analytical with Quasi Experiment with design pre-test and post-test with control group. The analysis used is univariate, bivariate analysis used paired T- test and Wilcoxon test. The population in this research were all Trimester II pregnant women in Singaparna Public Health Center area with a sampling technique using purposive sampling to obtain a sample of 50 pregnant women. Based on the results of the research found that there was an increase in the average levels of Haemoglogin in the intervention group from $11.62 \%$ gr to $11.79 \mathrm{gr} \%$, but these results were not statistically significant using the Wilcoxon test (P value 0.979 ). Control group (water) showed a decrease in haemoglobin levels from $11.68 \%$ gr to 11.38 gr\% and this result was not statistically significant using the Paired $\mathrm{T}$ Test. The conclusion in this research is an increase in the average level of $\mathrm{Hb}$ in the intervention group (orange juice). Recommendations There is a need for control of diet which can also have an impact on increasing levels of $\mathrm{Hb}$.
\end{abstract}

Keywords: iron tablets; orange juice; haemoglobin; fe; anemia

\section{Pendahuluan}

Sebanyak $40 \%$ kematian ibu di negara berkembang berkaitan dengan anemia dalam kehamilan.[1] Tahun 2012, angka kematian ibu tercatat mencapai 359 per 100 ribu kelahiran hidup. Data penyebab terbanyak kematian ibu di Indonesia yaitu perdarahan $28 \%$, eklamsi $24 \%$, inFeksi $11 \%$. Perdarahan merupakan penyebab utama yang menimbulkan kematian.[2] Perdarahan yang menyebabkan kematian pada ibu bisa terjadi pada saat kehamilan, persalinan dan nifas yang salah satu penyebabnya adalah karena anemia.
Anemia merupakan suatu keadaan dimana komponen di dalam darah yaitu haemoglobin dalam darah jumlahnya kurang dari kadar normal. Anemia kehamilan di sebut "potentional danger to mother and child" (potensi membahayakan ibu dan anak), oleh karena itu anemia memerlukan perhatian serius dari semua pihak yang terkait dalam pelayanan kesehatan.[3-4] Anemia gizi merupakan keadaan dengan kadar hemoglobin, hematokrit, dan sel darah merah yang lebih rendah dari nilai normal, sebagai akibat dari defisiensi salah satu atau beberapa unsur makanan esensial yang dapat mempengaruhi timbulnya defisiensi tersebut. Kekurangan pasokan zat gizi besi $(\mathrm{Fe})$ 
yang merupakan inti molekul hemoglobin sebagai unsur utama sel darah merah. Akibat anemia gizi besi terjadi pengecilan ukuran hemoglobin, kandungan hemoglobin rendah, serta pengurangan jumlah sel darah merah. Anemia zat besi biasanya ditandai dengan menurunnya kadar $\mathrm{Hb}$ total di bawah nilai normal (hipokromia) dan ukuran sel darah merah lebih kecil dari normal (mikrositosis). Tanda-tanda ini biasanya akan menggangu metabolisme energi yang dapat menurunkan produktivitas.[5]

Prevalensi anemia pada ibu hamil di Indonesia tahun 2013 sekitar 37,1\%.[6] Beberapa faktor yang dapat menyebabkan terjadinya anemia kehamilan diantaranya pendidikan, status ekonomi dan kepatuhan konsumsi tablet Fe. Mengkonsumsi tablet $\mathrm{Fe}$ sangat berkaitan dengan kadar $\mathrm{Hb}$ ibu hamil. Anemia banyak dialami ibu hamil disebabkan oleh kepatuhan mengkonsumsi tablet $\mathrm{Fe}$ ataupun cara mengkonsumsi yang salah sehingga menyebabkan kurangnya penyerapan zat besi pada tubuh ibu. [7]

Terdapat beberapa faktor yang mempermudah dan menghambat absorbsi zat besi dalam tubuh. Konsumsi buah-buahan yang mengandung vitamin $\mathrm{C}$ sangat berperan dalam absorbsi besi dengan jalan meningkatkan absorbsi zat besi non heme hingga empat kali lipat. Sedangkan faktor yang menghambat adalah tannin dalam teh, fitat, fosfat, dan serat dalam bahan makanan.[8]

Pemberian tablet besi bersamaan dengan zat gizi mikro lain (multiple micronutrients) lebih eFektif dalam meningkatkan status besi, dibandingkan dengan hanya memberikan suplementasi besi dalam bentuk dosis tunggal. Oleh karena itu, untuk meningkatkan penyerapan besi didalam tubuh, suplementasi besi yang diberikan perlu dikombinasi dengan mikronutrien lain, seperti vitamin A dan vitamin C. Absorbsi zat besi yang efisien dan eFektif adalah besi dalam bentuk Ferro sebab mudah larut, untuk itu diperlukan suasanan asam di lambung dan senyawa yang dapat mengubah Ferri menjadi Ferro di dalam usus adalah vitamin $\mathrm{C}$.

Penelitian lain mengatakan bahwa ada hubungan asupan vitamin $\mathrm{C}$ dengan kadar haemoglobin pada ibu hamil di klinik Usodo Colomadu Karangayar. Vitamin $\mathrm{C}$ dan zat besi membentuk senyawa askorbat besi kompleks yang mudah larut dan mudah diabsorbsi. [9]

Data tahun 201733.236 ibu hamil sebesar $7,78 \%$ yang mengalami anemia. Laporan Puskesmas Singaparna dari 581 ibu hamil sebesar
$6,71 \%$ yang mengalami anemia, sedangkan data ibu hamil yang diberikan tablet Fe di tahun 2017 sudah mencapai 97\%. [10] Melihat data tersebut cakupan tablet $\mathrm{Fe}$ sudah terpenuhi tetapi tetap saja masih ada ibu hamil yang mengalami anemia. Penanggulanagan anemia pada ibu hamil dilaksanakan dengan memberikan 90 tablet $\mathrm{Fe}$ kepada ibu hamil selama periode kehamilannya.

Berdasarkan latar belakang tersebut, maka peneliti ingin melakukan penelitian eFektifitas konsumsi tablet $\mathrm{Fe}$ dengan air putih dan air jeruk terhadap peningkatan kadar $\mathrm{Hb}$ pada ibu hamil.

\section{Metode Penelitian}

Jenis penelitian yang digunakan dalam penelitian ini adalah penelitian kuantitatif analitik dengan Quasi Eksperiment dengan rancangan pretest dan post-test with control group, dimana sampel akan dilakukan pemeriksaan $\mathrm{Hb}$ di awal dan setelah 2 bulan diberikan intervensi akan dilakukan pemeriksaan $\mathrm{Hb}$ kembali. Populasi dalam penelitian ini adalah seluruh ibu hamil Trimester II di wilayah Kerja Puskesmas Singaparna dengan tekhnik pengambilan sampel menggunakan purposive sampling sehingga didapatkan sampel sebanyak 50 ibu hamil. Tempat penelitian di wilayah Kerja Puskesmas Singaparna Kabupaten Tasikmalaya tahun 2019. Teknik pengumpulan data yang digunakan dalam penelitian ini dengan data primer. Sampel dikumpulkan di awal untuk pemeriksaan $\mathrm{Hb}$, sampel dibagi menjadi 2 kelompok intervensi dan kelompok kontrol. Intervensi diberikan jeruk kombinasi Fe sedangkan kontrol hanya Fe dan air putih saja. Jeruk yang diberikan adalah jenis jeruk lokal (jeruk jember) yang diberikan selama 2 bulan. Analisis yang digunakan dalam penelitian ini adalah analisis univariat dan bivariat. Analisis univariat untuk mengetahui gambaran deskriptif dari data-data yang dikumpulkan antara lain mean, median, standar deviasi, kadar $\mathrm{Hb}$, dan data tambahan yaitu karakteristik responden meliputi umur, paritas, jarak kelahiran dan status gizi. Sedangkan analisis bivariat dilakukan untuk melihat perbedaan kadar hemoglobin awal, hemoglobin akhir dan perubahan kadar hemoglobin antara kelompok perlakuan I dan perlakuan II. Penelitian ini menggunakan uji normalitas dengan uji Shapiro-wilk dan proses penelitian sudah dengan tahapan Ethical Cleareance dengan No. 2019/KEPK/PE/VI/0002. 
Tabel 1

Karakteristik Subjek Penelitian

\begin{tabular}{llcc}
\hline & Variabel & Frekuensi n = 50 & Persentase (\%) \\
\hline Usia & Reproduktif $(20-35)$ & 44 & 88 \\
& Risiko $(<20$ dan $>35)$ & 6 & 12 \\
\hline Paritas & Primipara & 13 & 26 \\
& Multipara & 37 & 74 \\
\hline Jarak Kelahiran & Baik $(>2$ tahun) & 33 & 89,19 \\
& Kurang baik $(\leq 2$ tahun & 4 & 10,81 \\
\hline Status Gizi Awal & Baik /Tidak KEK (LILA $>23,5 \mathrm{~cm})$ & 39 & 78 \\
pemeriksaan & Kurang baik /KEK (LILA $\leq 23,5 \mathrm{~cm})$ & 11 & 22 \\
\hline Status Gizi & Baik /Tidak KEK (LILA $>23,5 \mathrm{~cm})$ & 42 & 84 \\
Pemeriksaan akhir & Kurang baik /KEK (LILA $\leq 23,5 \mathrm{~cm})$ & 8 & 16 \\
\hline
\end{tabular}

Tabel 2

Distribusi rerata kadar $\mathrm{Hb}$ pemeriksaan $\mathrm{Hb}$ awal pada kelompok intervensi dan kontrol di Wilayah Kerja Puskesmas Singaparna Kabupaten Tasikmalaya tahun 2019

\begin{tabular}{ccccccc}
\hline No & Kadar Hb & Range & Min & Max & Mean & Std. Dev \\
\hline 1 & Intervensi & 4 & 9 & 13 & 11,62 & 1,02 \\
2 & Kontrol & 4,1 & 9,7 & 13,8 & 11,68 & 0,97 \\
\hline
\end{tabular}

Tabel 3

Distribusi rerata kadar $\mathrm{Hb}$ pada pemeriksaan $\mathrm{Hb}$ akhir kelompok intervensi dan kontrol di Wilayah Kerja Puskesmas Singaparna Kabupaten Tasikmalaya tahun 2019

\begin{tabular}{ccccccc}
\hline No & Kadar Hb & Range & Min & Max & Mean & Std. Dev \\
\hline 1 & Intervensi & 4,8 & 10,1 & 14,9 & 11,79 & 1,26 \\
2 & Kontrol & 4,2 & 9,8 & 14 & 11,38 & 0,91 \\
\hline
\end{tabular}

Tabel 4

Distribusi Perbedaan peningkatan kadar haemoglobin antara kelompok Intervensi dan kelompok kontrol di Wilayah Kerja Puskesmas Singaparna Kabupaten Tasikmalaya tahun 2019

\begin{tabular}{llcc}
\hline \multicolumn{1}{c}{ Kelompok } & Kadar Hb & Mean & P value \\
\hline Intervensi & Pemeriksaan Awal & 11,62 & 0,979 \\
\multirow{3}{*}{ Kontrol } & Pemeriksaan Akhir & 11,79 & \\
& Pemeriksaan Awal & 11,68 & 0,139 \\
& Pemeriksaan Akhir & 11,38 & \\
\hline
\end{tabular}

\section{Hasil dan Pembahasan}

Karakteristik subjek penelitian pada tabel 1 menunjukkan bahwa persentase tertinggi ketegori usia reproduktif sebesar $88 \%$, persentase terbanyak adalah paritas multipara yaitu $74 \%$, persentase jarak kelahiran dengan kategori baik yaitu 89,19 $\%$, persentase tertinggi status gizi baik/tidak KEK sebesar $78 \%$ di pemeriksaan $\mathrm{Hb}$ awal, dan persentase tertinggi status gizi baik/tidak KEK sebesar $84 \%$ pada pemeriksaan $\mathrm{Hb}$ akhir.
Tabel 2 menunjukkan rerata kadar Haemoglogin pada sampel kelompok intervensi (air jeruk) dengan kadar $\mathrm{Hb}$ terendah adalah $9 \mathrm{gr} \%$, kadar $\mathrm{Hb}$ tertinggi adalah $13 \mathrm{gr} \%$ dan nilai mean 11,62 gr\% serta pada kelompok kontrol (air putih) dengan kadar $\mathrm{Hb}$ terendah adalah 9,7 gr\%, kadar

$\mathrm{Hb}$ tertinggi adalah $13,8 \mathrm{gr} \%$ dan nilai mean $11,68 \%$

Tabel 3 menunjukkan rerata kadar Hemoglogin pada sampel kelompok intervensi (air jeruk) dengan kadar $\mathrm{Hb}$ terendah adalah 10,1 gr\%, kadar $\mathrm{Hb}$ tertinggi adalah 14,9 gr\% dan nilai mean 
11,79 gr\% serta pada kelompok kontrol (air putih) dengan kadar $\mathrm{Hb}$ terendah adalah 9,8 gr\% kadar $\mathrm{Hb}$ tertinggi adalah $14 \mathrm{gr} \%$ dan nilai mean 11,38 gr\%

Tabel 4 menunjukkan ada peningkatan rata rata kadar Haemoglogin pada kelompok intervensi dari 11,62 gr $\%$ menjadi 11,79 gr $\%$, tetapi hasil ini tidak bermakna secara statistik dengan menggunakan uji wilcoxon ( $\mathrm{P}$ value 0,979). Untuk kelompok kontrol (air putih) menunjukkan adanya penurunan kadar $\mathrm{Hb}$ dari 11,68 gr \% menjadi 11,38 gr \% dan hasil ini tidak bermakna secara statistik dengan menggunakan uji Paired T Test ( $\mathrm{P}$ value $0,139)$

Berdasarkan hasil penelitian didapatkan karakteristik responden berdasarkan umur yaitu sebagian besar antara 20-35 tahun sebanyak $88 \%$. Dari hasil tersebut sebagian besar responden termasuk dalam kategori usia reproduksi sehat dan berisiko rendah terhadap komplikasi yang bisa terjadi dalam kehamilan. Kehamilan di usia kurang dari 20 tahun secara biologis belum optimal emosinya cenderung labil, mental belum matang sehingga mudah mengalami goncangan yang mengakibatkan kurangnya perhatian terhadap pemenuhan kebutuhan zat-zat gizi selama hamil. Sedangkan umur lebih dari 35 tahun terkait dengan kemunduran dan daya tahan tubuh sehingga memerlukan energi yang besar karena fungsi organ yang makin melemah dan diharuskan untuk bekerja maksimal maka memerlukan tambahan energi yang cukup untuk mendukung kehamilan yang sedang berlangsung, usia kurang dari 20 tahun dan lebih dari 35 tahun akan meningkatkan resiko terjadinya anemia dan rentan terhadap masalah gizi lainnya.[4][11]

Melihat hasil penelitian dari semua responden yang diberikan tablet $\mathrm{Fe}$ dengan menggunakan air jeruk ataupun air putih, status gizi responden mengalami peningkatan. Pada awal pemeriksaan menunjukkan bahwa status gizi baik/tidak KEK sebesar $78 \%$ dan status gizi kurang baik /KEK sebesar 22\%. Setelah 2 bulan diberikan tablet $\mathrm{Fe}$ dengan menggunakan air jeruk dan atau air putih menunjukkan hasil bahwa status gizi baik/tidak KEK sebesar $84 \%$ dan status gizi kurang baik /KEK sebesar 16\%. Dari data tersebut status gizi baik/tidak KEK mengalami peningkatan sebesar $6 \%$ dari $78 \%$ menjadi $84 \%$.

Sesuai dengan teori bahwa status gizi akan mempengaruhin kadar $\mathrm{Hb}$, jika ibu dengan status gizi kurang maka akan beresiko terkena anemia (kadar $\mathrm{Hb}$ dibawah normal) sedangkan ibu dengan status gizi normal tidak beresiko terjadi anemia. jika seseorang status gizinya rendah (kekurangan karbohidrat dan protein) kemungkinan akan menurunkan kadar $\mathrm{Hb}$ dan meningkatkan resiko terjadinya anemia.[8] Hal ini sejalan dengan penelitian dimana $\mathrm{P}$ value $=0,009$ ( $\mathrm{P}$ value < $0,05)$ dapat disimpulkan ada hubungan yang signifikan antara status gizi dengan kadar haemoglobin pada ibu hamil.[12] Kurus dan gemuknya seseorang mencerminkan bagaimana asupan nutrisi orang tersebut, terutama karbohidrat sebagai sumber utama energi, serta protein dan lemak. Jika seseorang memiliki status gizi buruk atau kurang, maka kemungkinan besar orang tersebut menderita KEK (Kurang Energi Kalori) dan KEP (Kurang Energi Protein). Hal itu menandakan bahwa orang tersebut asupan karbohidratnya rendah, yang berarti bahwa orang tersebut beresiko mengalami anemia.[13] Tidak hanya itu responden yang mengalami penurunan kadar $\mathrm{Hb}$ (anemia) bisa dikarenakan status gizi yang kurang baik dan selain itu bisa juga dikarenakan pada ibu hamil yang baru pertama kali, sehingga responden tidak mengetahui tentang status gizi yang baik dan kurang .

Berdasarkan hasil penelitian juga didapatkan bahwa menunjukkan ada peningkatan rata rata kadar Hemoglogin pada kelompok intervensi dari 11,62 gr \% menjadi 11,79 gr \%, tetapi hasil ini tidak bermakna secara statistik dengan menggunakan uji wilcoxon, ( $\mathrm{P}$ value 0,979). Untuk kelompok kontrol (air putih) menunjukkan adanya penurunan kadar $\mathrm{Hb}$ dari 11,68 gr $\%$ menjadi 11,38 gr \% dan hasil ini tidak bermakna secara statistik dengan menggunakan uji Paired $T$ Test, ( $\mathrm{P}$ value 0,139 ). Adanya perbedaan antara kedua kelompok perlakukan ini menunjukkan bahwa pemberian tablet $\mathrm{Fe}$ bersamaan dengan zat gizi mikro lain lebih eFektif dalam meningkatkan kadar $\mathrm{Hb}$, dibandingkan dengan hanya memberikan suplementasi besi dalam bentuk dosis tunggal. Oleh karena itu, untuk meningkatkan penyerapan zat besi didalam tubuh, suplementasi zat besi yang diberikan perlu dikombinasikan dengan mikronutrien lain seperti vitamin $\mathrm{C}$.

Adanya peningkatan kadar $\mathrm{Hb}$ setelah diberikan intervensi (konsumsi $\mathrm{Fe}$ dengan menggunakan air jeruk) mengindikasikan bahwa vitamin $\mathrm{C}$ berperan dalam pembentukan substansi antar sel dan berbagi jaringan, serta meningkatkan daya tahan tubuh misalnya aktivitas fagositosis dari sel darah putih dan transportasi zat besi dari transFerin dalam darah ke Feritin dalam sumsum tulang, hati dan limpa. Vitamin C mempunyai peranan yang sangat penting dalam penyerapan 
besi terutama dari besi nonhem yang banyak ditemukan dalam makanan nabati. Bahan makanan yang mengandung besi hem yang mampu diserap sebayak 37\% sedangkan bahan makanan golongan besi nonhem hanya 5\% yang dapat diserap oleh tubuh. Penyerapan besi nonhem dapat ditingkatkan dengan kehadiran zat pendorong penyerapan seperti vitamin $\mathrm{C}$ dan faktor faktor pendorong lain seperti daging, ayam, ikan. Vitamin $\mathrm{C}$ bertindak sebagai enchancer yang kuat dalam mereduksi ion Ferri menjadi ion Ferro, sehingga mudah diserap dalam $\mathrm{pH}$ lebih tinggi dalam duodenum dan usus halus.[8]

Kebutuhan vitamin C pada wanita sekitar 75 mg per harinya. Dalam penelitian ini, responden dengan kelompok kasus diberikan 1 buah jeruk setiap harinya yang harus diperas dan dikonsumsi bersamaan dengan tablet $\mathrm{Fe}$. Dengan mengkonsumsi 1 buah jeruk, kebutuhan vitamin $\mathrm{C}$ yang didapat sekitar $54 \mathrm{mg}$, karena kebutuhan vitamin C lainnya bisa didapatkan dari makanan lain seperti sayur sayuran dan buah buahan lain seperti tomat, brokoli dll. Kandungan serat dalam jeruk tentu ketika berlebihan masuk kedalam tubuh akan menyebabkan diare. Terlalu banyak vitamin C (lebih dari $2.000 \mathrm{mg}$ sehari), akan menyebabkan mual, muntah, diare bahkan beresiko mengalami batu ginjal. Maka dari itu, disarankan untuk ibu hamil dapat mengkonsumsi vitamin $\mathrm{C}$ dalam jumlah yang cukup.Vitamin $\mathrm{C}$ mempunyai fungsi dalam metabolisme $\mathrm{Fe}$, terutama untuk mempercepat proses penyerapan $\mathrm{Fe}$ dalam usus dan proses pemindahannya ke dalam darah. Vitamin $C$ juga terlibat dalam mobilisasi simpanan $\mathrm{Fe}$ terutama dalam pembentukan hemosiderin dalam limfa.[14]

Dalam penelitian ini kami menggunakan jeruk yang mempunyai rasa manis atau tidak terlalui asam. Karena dikhawatirkan ketika ibu mengkonsumsi jeruk yang asam akan mempengaruhi asam lambung. Konsumsi jeruk atau buah buahan yang mengandung vitamin $\mathrm{C}$ sangat berperan dalam absorbsi besi dengan jalan meningkatkan absorbsi zat besi non heme hingga empat kali lipat. Mekanisme absorbsi ini termasuk mereduksi Ferri menjadi bentuk Ferro dalam lambung yang mudah diserap. [8]

Selain itu responden penelitian baik yang kelompok kontrol dan kasus diberikan penjelasan penjelasan terlebih dahulu terkait bagaiman cara konsumsi tablet $\mathrm{Fe}$ yang benar yaitu meminum ketika perut sudah kosong dan sebelum mengkonsumsi tablet $\mathrm{Fe}$ jangan mengkonsumsi makanan atau minuman yang dapat menghambat penyerapan tablet Fe. [8] menuliskan untuk dapat meningkatkan penyerapan zat besi dalam tubuh, suplementasi besi yang diberikan perlu dikombinasikan dengan mikronutrien lain seperti vitamin A dan vitamin C.

Penelitian ini sejalan dengan penelitian sebelumnya bahwa Peningkatan rata-rata kadar $\mathrm{Hb}$ paling tinggi pada kelompok Fe kombinasi jus jambu biji yaitu dengan peningkatan sebesar $17,12 \%$, kemudian pada kelompok Fe kombinasi vitamin $\mathrm{C}$ rata-rata peningkatannya sebesar $10,64 \%$, dan terendah pada kelompok Fe dengan peningkatan rata-rata sekitar 7,29\%.[15] Uji paired $t$ test kelompok $\mathrm{Fe}+\mathrm{jus}$ jambu biji, $\mathrm{Fe}$ kombinasi vitamin $\mathrm{C}$, dan tablet $\mathrm{Fe}$ masingmasing diperoleh nilai $\mathrm{p} 0,000 ; 0,001$ dan 0,018 $(\mathrm{P}<0,05)$ artinya ada perbedaan kadar $\mathrm{Hb}$ sebelum dan setelah intervensi 8 minggu pada masingmasing kelompok.

\section{Simpulan}

Berdasarkan hasil penelitian dapat disimpulkan bahwa Adanya peningkatan rata rata kadar $\mathrm{Hb}$ kelompok intervensi (air jeruk) dan Adanya penurunan rata rata kadar $\mathrm{Hb}$ kelompok kontrol (air putih) dari 11,68 gr \% menjadi 11,38 gr \%. Perlu adanya pengontrolan terhadap pola makan yang bisa berdampak juga terhadap peningkatan kadar $\mathrm{Hb}$

\section{Daftar Pustaka}

[1] WHO, Archived: Daily iron and folic acid supplementation in pregnant women. Geneva: In W. H. Organization (Ed.), 2018.

[2] R. Kementrian Kesehatan, "Riset Kesehatan Dasar (Riskesdas)," Jakarta, 2013.

[3] D. L. Lowdermilk, S. E. Perry, and K. Cashion, Keperawatan maternitas, 4th ed. EGC, 2013.

[4] M. I. IAC, Manuaba, Ilmu kebidanan, penyakit kandungan, dan KB. Jakarta: EGC, 2010.

[5] M. K. Dr. dr. Citrakesumasari, Anemia Gizi, Masalah dan Pencegahannya. Yogyakarta: Kalika, 2012.

[6] Kemenkes RI, "Laporan Hasil Riset Kesehatan Dasar Provinsi Papua Tahun 2013," Jakarta, 2013.

[7] M. Dian Litasari, AgusSartono, "Kepatuhan Minum Tablet Zat Besi Dengan Peningkatan Kadar $\mathrm{Hb}$ Ibu Hamil di Puskesmas Purwoyoso Semarang," J. Gizi Univ. 
Muhammadiyah Semarang, vol. 3, pp. 25-33, 2014.

[8] S. Almatsier, Prinsip Dasar Ilmu Gizi. Jakarta: Gramedia Pustaka Umum, 2010.

[9] D. widowati Devani Chyntiabadi caesaria, Elida soviana, "Hubungan Asupan Zat Besi Dengan Vitamin C Dengan Kadar Hemoglobin Pada Ibu Hamil di Klinik Usidi Colomadu Karanganyar," J. Kesehat. Masy., vol. 1, 2015.

[10] Puskesmas Singaparna, "Laporan Puskesmas Singaparna," Tasikmalaya, 2017.

[11] W. Kristiyanasari, Gizi Ibu Hamil. Yogyakarta: Nuha Medika, 2010.

[12] Sab'ngatun and A. Novitasari, "Hubungan Antara Status Gizi Dengan Kadar Hemoglobin Pada Ibu Hamil Trimester Iii," J. Chem. Inf. Model., vol. 53, no. 9, pp. 1689-1699, 2018, doi:
10.1017/CBO9781107415324.004.

[13] Waryana, Gizi Reproduksi. Yogyakarta. Pustaka Rihama. Yogyakarta: Pustaka Rihama, 2010.

[14] P. Sarwono, Ilmu kebidanan. Jakarta: Yayasan Bina Pustaka, 2010.

[15] N. Q. Rista Andaruni and B. Nurbaety, EFektivitas Pemberian Tablet Zat Besi (Fe), Vitamin C Dan Jus Buah Jambu Biji Terhadap Peningkatan Kadar Hemoglobin (Hb) Remaja Putri Di Universitas Muhammadiyah Mataram," MidwiFery J. J. Kebidanan UM. Mataram, vol. 3, no. 2, p. 104, 2018, doi: "10.31764/mj.v3i2.509. 